\title{
CONTEMPORARY TRENDS IN THE TOURISM MARKET
}

\author{
Dushica Mateta Gigova \\ State University "Goce Delchev" - Stip, Faculty Of Tourism And Business Logistics \\ Section - International Tourism
}

Professional Paper

doi:10.5937/jouproman4-11227

\begin{abstract}
By the term market, in the widest since of the word, means a set of everyday relations of demand and supply to various types of goods, in which the exchange is carried out through the intermediation of money. As a mixture of the interaction between supply and demand, the market is actually a mixture of the overall supply and overall demand for goods and services, production resources and loans. These relations act constantly, in a certain time and place. It is a mixture of legal interaction between supply and demand.
\end{abstract}

The market is a summation of all facilities, zones and offices that provide organized and constant contact between buyers and sellers, or encounter of the supply and demand, which leads to the implementation of goods. The basic idea of the market can be defined as material and immaterial centralization and concentration of supply and demand in one or more economic goods within a specified period of time.

Accordingly, in the widest sense, the market is part of the socio-economic system and its functions are - by means of it to realize reproduction of material production, and the occalist manufacturing relations. The market is a particular place where you meet the seller and the buyer and where are concluded bills of sale. It can be: shop, marketplace, daily or weekly market, an annual trade fair (fair), contemporary fair of samples, stock market, purchase or sale of department of industrial or wholesale trading company. The term "market" can mean territory (zone).

Key words: Offer, demand, buyers, sellers, national, import - export

\section{CONTEMPORARY TRENDS} IN THE TUORISM MARKET

\section{The tourism market and its specificities}

From this standpoint it can be:

- $\quad$ Local - when it covers one area of the economy of the State;

\begin{abstract}
- $\quad$ internal (national) - that covers the whole the territory of a state and

- external (imported and export) - when it covers market beyond the border of the state.
\end{abstract}

From the perspective of the type of goods, there are different types of markets, such as market of consumption goods, market resources for manufacturing, labor market, money market, market of bank paper and so on. From the perspective of the branch or area of production, whose articles come out on the market, we distinguish: market of industrial products market, in agricultural products and others.

The market of agricultural products is a narrow market, because it only applies to agricultural products and procucts with which satisfy the production requirements of the agriculturalists. This singularity in the market of agricultural products is resulting from the singularity of the agriculture as an industry. These specifications are the result of the seasonal nature of agricultural production t.e the uneven supply of agricultural products on one hand and the continual need for these products on the other.

The market provides a snapshot of the economy and shows manufacturers in what direction and how should they direct their initiative. It also assess whether the amount of work spent for manifacturing of the good, corresponds on the needs of society and whether the amount of work was socially useful. 
In any economy the exchange of goods is done through the market. Since the exchange of goods is necessary for their implementation, and normal and continuously conducttion of the process of reproduction - therefore the role of the market in that process is primary and important. However, there are differences in the functions and significance of the market in the capitalist economy and the economy in transition. These differences originate from the different character of the production.

Based on the valorization of the required labor in terms of workers selfmanagement, the function of the market is - an adequate contribution of the individual to realize his optimally act on economic development.

The market in our society has several functions. The market impacts on the pricing of certain goods. Organizations of associated labor market to determine the results of its operations. Our market and has one important function and that is realizing of the workers income and helps the employees to check their real values

In conditions of individual producers in agriculture and handicrafts, the market has the feature to associate these manufacturers with the social branch and this includes in the construction of socialism. In our conditions of socialist commodity production, and planning development of economy, the market determines the position of producers in bilateral economic relations. Such a market is also provided for self-producers at the current level of development of production. In terms of commodity production HTA can not exist without market, even as the market could not exist without various HTA.

The market encourages organizations to join work to increase the efficiency of its operations and its work to comply with market needs. The positive impact of the market on the development of production is reflected in multiple directions. In the first place, given the existence of the market, the commodity character of production and the operation of economic laws, manufacturers must actively treat problems of production and its realization. All production HTA or collectives of direct producers must adjust production volume, structure and range depending on the placement possibilities, so in terms of market competition, they have to fight for a better quality their products.

The market also acts positively on the development of production, it encourages OAL for rational production and division of labor between different business organizations to accelerate the process of specialization and cooperation, and given that such forms of cooperation between individual HTA increase their competitive abilities in the market in the ratio of other HTA because they allow by such operations to cut prices on the cost of their products.

The implementation of social plans through the market is actually a reality check of planned relations in the process of manifacturing, planned processions and the individual instruments relating to production, distribution and exchange.

Thus, the emergence of the market can be assessed as a sort of indication of possible corrections and changes already adopted business plans. From all mentioned shows that a great importance on the market in building the socialist economics of today's level of our economic development. However, as is well known, the community must take adequate measures of administrative intervention (social plans and tools that they contain a series of regulations and measures) - to set certain limits on the operation of the market. 
That means you need to set appropriate boundaries in which it is impossible to allow free interaction of the spontaneous actions of the market, or completely operation of economic laws, because it would lead to anarchy and would pose a danger to the economic development of the country.

This chapter analyzes the most important components of the tourism market of empirical way. Primarily it refers to determining the needs tourism and tourist spending, followed by analysis of the touristic flexibility between supply and demand, and the factors that condition.

Considering the fact that the tourism market is not homogeneous structure of consumers, when considering their characteristics and requirements in detail to analyze the application of market segments in this area, in terms of the application of the elements of marketing conception. Considering that promotion of tourism is an important area for the study of the tourism market and this issue will be adequately addressed. Based on the theoretical foundations of the tourism market, the following section should focuses on the issues of research of the tourism market, which is outlined in a separate section because of exceptional importance which is the study of turizmot. At the same time it represents an important basis for the application of marketing conception in tourism.

\section{Tourism market and its dimensionality}

The study of human needs is an important field and it can find aplication it the marketing needs. For these types of studies, they use scientific methods in the field of statistics and mathematics and scientific achievements in sociology and psychology. The needs are defined as discomfort associated with the awareness that there is a means by which inconvenience can be removed. ${ }^{1}$

In the literature there are a larger number of classifications of tourism needs but here we will mention the following: ${ }^{2}$

1. Necessary needs - those are needs that are related to the existence of man in the biological sense (food, water, etc.)

\section{Additional needs can be:}

a) General cultural needs

b) Luxury goods -when a priority is given ti the needs, normaly, it must first meet the necessary and then additional.

With the development of productive forces, science, technology and material basis increases national income which creates realistic grounds for raising living standards. This creates favorable conditions for the fair implementation of desires bound to meet additional needs. In additional needs can rank tourist needs for developing countries with a number of layers of necessary needs. You can say that in all countries, irrespective of level of development, tourism needs to part from occurring as required needs as a factor for preserving the working capacity of the population

Saturation point - By the term saturation point is understood fully (totally) satisfaction of the needs.

It is interesting to analyze how the tourist needs behave from the point of saturation .Because the degree of elasticity of the necessary needs is relatively small and is linked to the existence of the individual in a biological sense, we have a relatively rapid achievement of the level of fully satisfying . ${ }^{3}$

\footnotetext{
${ }_{2}^{1}$ A.Bazala - Metodi i istrzivanja trznista Zagreb.

2 Manfred Helzer_Die Motive des modernen Tourisms - der fremdenverkehr, 21

${ }^{3}$ S.Unkovic cit. Part page. 104.
} 
It means within this group needs, there are limited possibilities for their expansion. This course is a general formulation of the characteristics of the necessary needs from this point of view. In specific cases it is necessary to determine the degree of elasticity and saturation points based on appropriate research.

Unlike the first group needs, the second group, the additional needs has a much greater degree of flexibility and relatively harder reaches the point of saturation. Based on previous research can extract one category of goods that has the ability "unlimited spread" or can not get to the point of saturation needs. ${ }^{4}$ The need for durable products (car, TV, etc.) Much more quickly reach the point of saturation of tourist potrebi.It's similar with the various kinds of cultural goods (cinema, theater, etc.).

According to Kraft, tourist needs can not be imagined in the sociopsychological sense, therefore individuals who have financial capabilities to become tourists and gain travel habits will always strive to use more complex and better services to travel to new and remote areas, and to use their free time to satisfy tourist needs.

\section{Tourism, the tourism supply and demand and changes in the contemporary environment.}

Tourism needs precede tourist spending . "Depending on the quantity of tourist needs and purchasing capacity of the population is a rise of tourism demand .The conditions for tourist demand are generated at the moment the holders of tourist needs (individual or family) have the appropriate money supply and time to meet tourist needs ". 5 Tourist spending is considered that part of national income

\footnotetext{
${ }^{4}$ K. Kraf - Der touristiche Konsum - Bern.

${ }^{5}$ S.Unkovic "" Ekonomika turizma“ - cit. delo Beograd, page 105.
}

that the population stands for tourism purposes.

If tourist spending is viewed in national terms then it comes out that it is part of national income or personal consumption of the population which is provided of tourist trips within the country or abroad. ${ }^{6}$

From this it follows that tourist spending depends of the national income and its distribution, or the possibilities of allocating an appropriate proportion of personal consumption of the population. Available data show that a high degree of interdependence between the level of economic development and the level of living standards of the population on the one hand and tourist spending on the other.

For example, in the US in 1967 it has spent for tourism purposes about 30 billion dollars and the trips to the US 26 billion, and travel abroad 4 billion in tourist spendings. So it participated with $4.9 \%$ of the national income in that year, ie $5.9 \%$ by weight of disposable income. However, although the population of this country is spending such a high percentage of foreign travel, however arising (if viewed in relation to other developed countries) the americans in terms of national income spent at least relatively. in terms of population or possessors of tourism needs to travel abroad every 1000 residents in 1969 spent these dollars in these countries: ${ }^{7}$

\footnotetext{
${ }^{6} \mathrm{~S}$. Unkovic-cit. Delo page 105.

${ }^{7}$ OECD:International Tourism and Tourism Policy in OECD Member Vountries str 28.
} 


\begin{tabular}{|l|l|}
\hline Switzerland & 58.5 \\
\hline Canada & 56.9 \\
\hline Sweden & 5.80 \\
\hline Denmark & 50.1 \\
\hline Benelix & 45.5 \\
\hline Netherland & 42.0 \\
\hline Norway & 32.5 \\
\hline W.Germany & 31.2 \\
\hline
\end{tabular}

\begin{tabular}{|l|l|}
\hline France & 20.7 \\
\hline USA & 16.7 \\
\hline
\end{tabular}

Such problems clearly point to the difficulty of establishing the scope and structure of tourist spending on domestic and foreign markets. For determining the tourist consumption of domestic tourists mainly use the following methods: ${ }^{8}$

1. A method of assessment based on realized tourist turnover (number of domestic tourists, their accommodation and average daily consumption by types and categories of facilities for acomodation).

2. Method of periodically surveying tourists Although the first method is used for determination of tourist spending on the local and foreign tourists, is considered the method of surveying tourists is far more accurate and allows more realistic to establish tourist spending. In determining the tourist consumption of domestic tourists special problem is the determination of the benefits that many tourists use as traffic facilities for acomodation and others. While in tourist

\footnotetext{
${ }^{8}$ S. Unkovic- cit. Page 106.
}

spending of foreign tourists tourists themselves provide funds for this purpose, if the domestic tourists use various incentives and various resources (budget funds, funds of SEZ plans, from business, etc.).

In our country,for determination of tourist spending by foreign tourists are also used two ways:

1. Determination of tourist spending based on foreign exchange income registered in National Bank.

2. Determination of tourist spending based on occasional surveys of foreign tourists. The first way includes tourist spending by foreign tourists on the basis of foreign exchange inflows and implemented through banks, exchange offices, payment of external partners, revenue in respect of transport services and others.

The application of this method can be obtained only global idea about the total amount of consumption of foreign tourists. 
With this not covered foreign currency revenue the private economy collects, illicit private clearing and others. Also, when using this method should be very careful, especially when using the data concerning the structure of tourist spending in countries that send tourists because tourists do not pay the services only in local currency, on the basis what determines the foreign currency inflow of foreign tourists from certain countries (eg.: tourism services in dollars not only pay but also tourists from US dollars in pay and tourists from many different countries). ${ }^{9}$

The other method, based on a survey with a sample gives as well as domestic tourists much more reliable data and therefore in practice are increasingly used to determine the tourist consumption. ${ }^{10}$ The structure of tourist spending represents a significant indicator of the level of development of tourism in a country or place. The high percentage of expenditure on accommodation, food and transport and the relatively small share of expenditures for other goods (souvenirs, entertainment, etc.) Are indicative of relatively underdeveloped tourism economy of the respective country and location. The opposite conclusion can be drawn in the case of relatively better participation of other expenses in respect of expenses for food, accommodation and transport. Kraft has found that foreign tourists on average spend $50 \%$ of its budget for accommodation and food tourism market $25 \%$ for transport and $25 \%$ for other. Although these data can be used for orientation for global research actions yet there are a number of factors that affect the tourism consumption of the country. General determinant is that in developed

\footnotetext{
${ }^{9}$ S.Unkovic- '’Mogucnosti jugoslovenskog turizma na americkom trznistu' 'turiskicka stampa Beograd, page 12

10 "Istazivanje turistickog trznista", simpozium vo Dubrovnik
}

countries, tourist spending is more developed and undeveloped back in.

It is difficult to give a general formulation of tourism demand because it is influenced by many factors. However, it can be stated that its basis represent human needs for travel within the country and abroad for tourist purposes.

According to this tourist needs as a basis for tourism demand, become relative economic strength in terms of demand, even when it can be expressed and confirmed through solvency of holders of tourist needs. In other words the relationship between travel and tourism demand needs always depend on the socioeconomic conditions. This statement is significant, because of the bourgeois economic and the relationship between human needs and demand often boil down primarily to the wishes of the holders for the purposes of the possession of certain products and services, regarding the willingness to pay a price.

As noted, many factors affect the tourism demand. Previous exposures yielded more insight on some of them. This section will give a proper classification of factors, especially without entering into a detailed explanation of their actions. However, before this classification, will give a brief overview of some existing classifications of the factors of tourism demand. For example, all factors that influence the formation of tourism demand S. and H. Markovic splits into two groups, namely the objective and subjective factors. Objective factors of tourism demand are those that are independent of the behavior of individuals. Conversely, factors that can reflect the individual possibilities and affinities of individuals are called subjective factors.

The group of objective factors S. and $\mathrm{H}$. Markovic are included the following sub-groups covering a number of individual factors: 
$\begin{array}{ccc}\bullet & \text { working } & \text { environment } \\ \text { (urbanization, population density, the }\end{array}$ general level of civilization and cultural environment influenced by technical means, political conditions etc.).

- natural setting;

- free time (paid free time, parttime, vacation, etc.);

- means free (level of national income level and living standards etc.).

- other objective factors of demand (social and tourist flows, incentives and benefits, the existence of various resorts et seq.

- social and political organizations of the initiative character, organization of tourist savings etc.).

S. and H. Markovic consider subjective factors of demand are such factors which are reflected in subjective behavior of individuals, based on increasing the action of objective factors. Namely, despite the existence of objectively favorable factors, it is felt that the man depends on whether their free time and their money will be used for tourism or other purposes. Such decisions usually come within the scope of its subjective view of tourism. The authors suggest special meaning in this group of factors is fashion, behavior of others, prestige .... In case of deciding to take on a tourist trip. The authors state that the subjective factors of tourism demand based on psychological moments.

Recognizing the starting point, you can accept the said classification of the factors of tourism demand, it should be noted that its application is not suitable for the analysis of tourism demand from a market perspective. Specifically, the authors of this paper do not even consider the factors of tourism demand from a market perspective, but in terms of the analysis of the general factors of tourism, under the consideration of issues on the fundamentals of tourism, so from that aspect should be considered given classification.

Group of authors also divided the factors of tourism demand in two main groups, namely the subjective and objective factors. Subjective Factors include: personal inclinations of man for purposes of tourism, cultural heritage (tradition and education), personal needs (recovery, relaxation, and recreation), social environment (political situation, social status, fashion, family relationships etc.). Objective factors of demand do: industrialization, demographic growth, the class structure of society, political conditions, social system, economic development, national income and income of families, social policy, working conditions and paid annual leave the employee people. As can be seen, and the group of authors in the said work travel all the objective and subjective conditions in which existing holders of tourist needs as a basis for grouping and determine the individual factors of the tourist demand.

We can say that the authors addressed the most important individual within these groups, but certainly very difficult to draw precise boundary between individual subjective and objective factors. For example, if considered income of the population can freely say that it is like under the influence of objective factors (general level of economic development of the country, etc.) And under influence on subjective factors (personal standard of living individuals to which it can influence). Similar is the case with some other listed factors, such as for example the case of cultural heritage, which could rather be included in the group of objective rather than subjective factors. 
Not going into deeper into the analysis of the above mentioned classifications of the factors of tourism demand, we will try to formulate appropriate classification, which too would correspond to market access. On this occasion we will not start from the grouping of factors in terms of the ability of individuals to influence them, but on condition that certain factors potential tourism demand, no matter in which direction it will orient. The second of these groups of factors acting exactly the tourism demand to orient toward specific countries, regions or organizations of the tourism industry.

So, the first groups, which we call general factors affecting tourism demand in general, i.e., creates conditions for tourism demand in a particular social environment, i.e. a source of demand. Unlike this group, the second group, which we call specific factors, determines tourist demand for the services of a country, region or company of the tourism industry.

Further, will give an overview of each factor individually under the mentioned groups, not entering it in explaining the specific effect of these factors, because there is no special need for it. The most common factors of tourists demand:

- characteristics of the social system of a particular country;

- Political and economic conditions in the country and the world (level of general economic development, political situation in the world in terms of the existence of normal travel conditions, attitude of the governments of individual countries to travel for their citizens abroad and certain countries etc.).

- characteristics of social policy in the country (paid vacations, travel incentives existence and use of holidays, health policy etc.).
- achieved level of industrialization and urbanization (air pollution in urban areas, spacious zagushenost urban settlements etc.).

- characteristics of demographic growth and its structure globally and in individual countries;

- general cultural level of citizens;

- level of tourist culture;

- level of development of travel habits;

- tradition and fashion for travel;

- the natural environment in which people live;

- socio-economic characteristics of the population of a country or region (in terms of the general standard of living, the structure of households according to the level of annual income, education level, occupation, sex and age structure);

- general development of traffic and transport links;

- general level of prices of tourist services in domestic and international tourism;

- The quality of tourist services and tourist offer;

- General development of tourist propaganda etc.

The aforementioned subgroups factors include a number of individual factors, so from that aspect can be carried further division. These factors are discussed in terms of the possibilities of subjects them to act, at the same time have the character of objective and subjective factors. Some of these factors it is possible to perform clear and precise distinction, because in this case it is important that all the above mentioned factors act towards creating general conditions for the emergence of tourist demand with a certain intensity. 
Group of specific factors, as already mentioned, covers the factors that influence the concentration of tourism demand in certain precise directions, ie demand service given countries, regions or enterprises of the tourism industry. It should be noted that all the above mentioned general factors affecting the intensity of tourism demand and, therefore, the volume of demand for services in a certain area. Despite these factors affect tourism demand and specific factors such as:

- tourist monopoly of certain countries or regions (in terms of exceptional historical and natural attractions);

- geographical and climatic conditions in a given area;

- characteristics of the social and political system of a particular tourist country;

- distance of tourist country or region of the sources of demand and costs of transportation;

- existence of adequate roads and transport links that gravitate towards a particular country or region, reviewed in terms of sources of demand;

- existence of adequate accommodation and food in relation to the demands of tourists who are in some sources of demand;

- existence of adequate information about the conditions in the given country, as well as propaganda satisfactory in terms of the sources of demand;

- the level of prices of tourist services in a particular country or area turstichka;

- competitive comparative advantages in the area of prices of tourist services and their quality, natural and historical attractions, the quality of the promotional activities, etc.;

- formalities connected with the entry of foreign tourists in the country (visas, customs control, etc.);
- the position of the population where the source of demand in terms of a specific country or travel area so. All the above mentioned factors affect the actual place of tourist country or region in the distribution of tourism demand in international and national frameworks.

\section{The role and significance of the animator and animation in contemporary tourist offer}

In contemporary travel literature there are different aspects of the term animation. Some authors talk about relaxation, physical or psychological relief, some authors believe that tourism is animation entertainment, while others highlight its communicative aspects. In this context Joost Kripendorf highlights "Many tourists are helpless and lonely in his new environment, difficulties in friendships with people or find it difficult to do something that is not accustomed at home. Freedom confusing. Everyday life created excessive blockages and obstacles that buried the ability. "11

Accordingly animating after Joost Kripendorf should be understood as "Giving guidelines cultured trips, and the goal of animating is to make tourism more human ... and to encourage the full development of great personal potential that lies in every person."

In modern terms, it is known that comes to alienation of man by man as a result of urbanization and industrialization. This disposal is found during the travel movement. In this context is particularly important expression of Erich Fromm: "Tourist starts on a journey with his camera, she looks for, and the result of the trip is a collection of photographs which replaces experiences." 12

\footnotetext{
${ }^{11}$ JostKripendorf: "Putujucecovjecanstvo", SNL I Zavodzaistrazivanjeturizma, Zagreb, str. 133-134.

${ }^{12}$ E. From: "Zdravodrustvo", Rad, Beograd, str. 144.
} 
It is to be noted that, on the other hand, in connection with the research on motivation in tourism "new experience" is actually one of the main motives for tourist travel. The very experience an active attitude towards tourist values ie in its foundation the need for exploring new and unknown horizons, relationships, processes and problems M. Zvonarevikj them among the primary social needs. The experience is the reciprocal of the alienation of modern man. The question is how the animation in tourism, as the instigator of active participation and creativity, can act on the alienation and passivity of tourists. How through the program of tourist animation, culture - the value content can free time to form as a time of "real life"? The animation must be aimed for this purpose, because it is actually a cultural activity in tourism. The modern tourist, resident of the urban environment, often unable to establish contact with other people, even though he feels it need - say modern sociologists.

The need for company and permanent contact with other people tourists appears as one of the foundations in motivating tourists to tourist movement and all that is because of the lack of pleasure in everyday life. It should be noted that communication is an integral segment of the animation. Therefore form smaller groups within the hospitality table, thus providing better communication, hence the deliberate formation of groups is one of the tasks of animation in tourism.

Animator appears as intermediary whereby tourists are starting to communicate through participation in sports activities, sightseeing and walking tours, cultural activities etc. -zabavni. To achieve its goal, the animation must seek answers to questions that otherwise deals Social Psychology:

1) How are the groups formed? and
2) Why are the individuals included in the group and become its members?

For animation still the most important is the formation of groups to achieve the goal: a common activity that will be attractive enough to attract tourists and urged them to join the group. If animation is treated from aspect of the tourist offer, it should be treated as an integral part of the offer. It should be treated equally with other services such as accommodation and food. Based on the above it can be concluded that it is paramount importance of animation in tourism. Its importance is reflected in the fact that, on the one hand meets the needs and preferences of tourists and motivates you to stay active through animation programs. On the other hand increase economic effects. The goal of the animation is to create such programs will be based on the wishes and interests of tourists will meet their needs and make their stay more intricate.

Unfortunately, it can be concluded that not enough attention on this issue in $\mathrm{R}$. Macedonia is high time to carry out radical changes in attitudes and notions of directors who are involved in tourism, to animation as a major segment of the tourist offer and as an important condition for quality services.

But we get strong impression that there is adequate preparedness for implementing the initiative. Promotion of new professional staff would overcome indifference, the indifference of current managers in hotels, resorts and campsites. They completely to boost the development of tourism. It is possible to use and valorization of tourist values available to our country through programs of animation because it is the most important way of using leisure tourism. 
To realize its goal, the tourist animation must be guided by certain principles. There are several principles, but most important are these two:

1. Principle of freedom and

2. Principle of activity

The principle of freedom is one of the fundamental principles for the use of leisure time and means that the activities of leisure time should not be prescribed, but should be left to the individual choices. It is necessary to point out that programs animation should never be a constraint. It can be concluded that the observance of this principle actually allows "quidance of tourists" and "serving" the interests of tourists. It actually is the "instigator of free choice." ${ }^{13}$

The second principle is the principle of action. With respect to this principle can be stated that the animation should aspire to those contents which enable active participation of tourists. Regarding the participation of tourists in the programs of animation are two basic types:

A) Programs in which tourists are active participants. This means that tourists are directly involved as participants, which means that it was in these programs may come to the fore creativity of tourists;

B) programs in which tourists are relatively passive viewers, audience.

More programs can be organized in such a way to initiate active or passive participation of tourists and the level of activity depends on the organization of the animation. If for example picnic is organized in a classical way, tourists are passive viewers. They are active if they participate in the program for picnic on

\footnotetext{
13 D-r RadoslavaRavkin: “Animacija u turizmu”, Zalozba, mladinskaknjiga, Zagreb, str. 16
}

preparations, execution of tasks during the picnic and more. Based on the foregoing it can be concluded that the animation should be targeted to those forms and contents that require active participation of tourists.

\section{Conclusion}

The market is a summation of all facilities, zones and offices that provide organized and constant contact between buyers and sellers, or encounter of the supply and demand, which leads to the implementation of goods. The basic idea of the market can be defined as material and immaterial centralization and concentration of supply and demand in one or more economic goods within a specified period of time.

Tourism needs precede tourist spending . "Depending on the quantity of tourist needs and purchasing capacity of the population is a rise of tourism demand. The conditions for tourist demand are generated at the moment the holders of tourist needs (individual or family) have the appropriate money supply and time to meet tourist needs ". Tourist spending is defined as follows:" Tourist spending is considered that part of national income that the population stands for tourism purposes.

If tourist spending is viewed in national terms then it comes out that it is part of national income or personal consumption of the population which is provided of tourist trips within the country or abroad.

From this it follows that tourist spending depends of the national income and its distribution, or the possibilities of allocating an appropriate proportion of personal consumption of the population. Available data show that a high degree of interdependence between the level of economic development and the level of living standards of the population on the one hand and tourist spending on the other. 


\section{Used literature}

1. А.Базала - Методи истраживања тржишта Загреб.

2. Manfred Helzer_Die Motive des modernen Tourisms - der fremdenverkehr, 21.

3. K. Kraf - Der touristiche Konsum - Bern.

4. С.Унковиќ „Економика туризма “ цит. дело, Београд

5. OECD:International Tourism and Tourism Policy in OECD Member Vountries.
6. С.Унковиќ - „Могучности југословенског туризма на америчком тржишту“ туристичка штампа Београд

7. Истраживање туристичког тржишта“ симпозиум во Дубровник.

8. Jost Kripendorf: "Putujuce covjecanstvo", SNL I Zavod za istrazivanje turizma, Zagreb.

9. E. From: "Zdravodrustvo", Rad, Beograd.

10. D-r RadoslavaRavkin: "Animacija u turizmu”, Zalozba, mladinska knjiga, Zagreb. 